Evgeniya Desnitskaya

\title{
5 Nonagonistic Discourse in the Early History of Indian Philosophical Debates: From Brahmodyas to the Mahābhāșya
}

\section{Introduction}

One of the main problems in the contemporary study of premodern Indian culture is the search for the appropriate conceptual means of interpretation. In the case of textual studies, this problem may appear less acute since, in many instances, traditional modes of interpretation are provided by the commentaries. Still, it would certainly be naive, from a gnoseological perspective, to deny conceptual means and modes of interpretation merely on account of their absence in the commentaries. In the following passage, W. Halbfass underlines the inevitable difficulties a modern scholar confronts in studying an ancient culture:

[. . .] Understanding cannot amount to slipping into somebody else's skin, as it were, and to comprehend or experience the foreign, the other simply in its own identity, or by coinciding with it. Understanding ancient Indian thought cannot mean "becoming like the ancient Indians," thinking and seeing the world exactly like them. We are not capable of such "objectivity," and if we were, we would obviously not be "like the Indians." The goal of a radical "philosophical єлохп," an unqualified abstention from one’s own background and presuppositions, is unrealistic and undesirable. We cannot and need not "disregard" ourselves in the process of understanding. ${ }^{1}$

While recognizing the utility of emic ("insider") concepts within Indian culture, etic ("outsider") concepts can be introduced for the sake of the comprehensiveness of inquiry. Etic concepts are needed especially when we study those aspects of Indian culture that were not categorized "from within," i.e. by the innate means of self-reflection elaborated in Indian culture. To undertake historiographical work and philosophical analysis, scholars can productively make use of conceptual tools from the contemporary humanities.

One relevant example of a concept of this kind is the central topic of this volume, i.e. confrontation as social interaction. Initially elaborated in social sciences and anthropology, this concept has a long history in studies of premodern Indian

1 Wilhelm Halbfass, India and Europe (New York: State University of New York Press, 1988), 164.

Note: This work was supported by the Russian Science Foundation (RSF) under grant 18-78-10001.

Ә Open Access. (C) 2020 Evgeniya Desnitskaya, published by De Gruyter. (cc)BY-NC-ND This work is licensed under a Creative Commons Attribution-NonCommercial-NoDerivatives 4.0 International License.

https://doi.org/10.1515/9783110557176-006 
culture. Confrontation or agonism can be traced back to Indo-Aryan mythology and social practices; to the "potlatch festivals" depicted in Indian epics and elsewhere; and to contests between Vedic poets (viväda). The competitions between priests in the Brāhmanas (brahmodya) that evolved from these contests were less agonistic. Later, a different tradition of intellectual confrontation, namely rational philosophical disputes $(v \bar{a} d a)$, contributed a new layer to the Indian landscape of argumentation. As the dynamics of $v \bar{a} d a$ (elaborated in the Carakasaminitā or Nyāyasūtras) were generally accepted in subsequent generations of intellectual discourse, it may seem self-evident that a "normal" intellectual discussion in premodern India exhibited the properties of confrontation: with participants striving to justify their own respective viewpoints and disprove those of their rivals.

Perhaps surprisingly, there are also passages in early prephilosophical texts that contradict this general statement. Ritualized brahmodyas, disputes in the Upanișads, and discussions in grammatical works were structured as dialogues, but ones that did not fit the agonistic pattern that later became normative. The study of these nonagonistic intellectual practices in the early history of Indian philosophy is promising, because it may shed light on possible discrepancies between normative ideals and intellectual life as practiced. As the early history of Indian debates is generally reconstructed through textual evidence, the question may arise whether dialogues in these texts represent actual communication practices, or merely serve as narrative devices adopted by the authors for other reasons. To answer this question, I will analyze instances of nonagonistic argumentation in Brāhmaṇic brahmodyas, the Upaniṣads, and the Mahābhāsya with the aim of revealing shared patterns and identifying possible affinities between ritual debates, the philosophical strategies of the Upanișadic thinkers, and those of the ancient grammarians. While it may be tempting to consider textual debates to be reflections of the structure and dynamics of human communication, my analysis of the pragmatic structure of the texts shows that, in many cases, dialogic discourse was a textual strategy intended to create a multivocal perspective. This strategy can be also designated as polyphony, the plurality of voices in the text, with each voice expressing a single aspect of reality. ${ }^{2}$ Instances of this strategy and its evolution can be traced over a considerably extended period of Indian textual history.

2 The concept of polyphony in textual studies was introduced by Mikhail Bakhtin, who applied it in order to describe the poetics of Dostoevsky's work: "A plurality of independent and unmerged voices and consciousnesses, a genuine polyphony of fully valid voices is in fact the chief characteristic of Dostoevsky's novels"; see Mikhail Bakhtin, Problems of Dostoevsky's 


\section{Classical Brahmodya: Agonistic or Ritualistic?}

\subsection{The Origin of Brahmodyas}

Indo-Aryan culture is generally considered agonistic, since features of contest or confrontation pervade both its ideology as well as its social life. The foundational cosmological myth was agonistic: the battle of Indra with his enemies. Definitive social practices such as chariot races, gambling, gift-giving, and word contests were similarly agonistic. All these activities can be considered parts of the general "potlatch festival," the ceremonial contest of two parties, ${ }^{3}$ that constituted the background of Aryan culture. ${ }^{4}$ Agonistic performances in Indo-Aryan society were highly ritualized, generally being related to seasonal rituals. The intellectual component of the potlatch - the ceremonial contests of poets (vivāc, vivāda) - was carried out at the New Year feast as a part of a "ritual that aimed at a renewal of life and the winning of the sun." 5 These contests constituted the part of reciprocity relations in which poets were involved. The rules of these contests have not been explicitly defined, as they belong to the "preclassical" period of Vedic ritual as opposed to the classical ritual of the Brāhmanas and Srautasūtras. ${ }^{6}$ They can be only reconstructed on the basis of comparative analysis of Rgvedic passages and the textual evidence of other Indo-European societies. ${ }^{7}$

These agonistic practices of poetic contests gave birth to brahmodyas, the earliest type of intellectual confrontation in India represented in textual form. Brahmodya (literally "uttering Brahman") is a formal exchange of riddles on ritual or cosmogony performed by priests in the course of sacrifices (especially royal ones, such as the Aśvamedha, Rājasūya, and Vājapeya). ${ }^{8}$ Examples of

Poetics, ed. and trans. Caryl Emerson (Minneapolis: University of Minnesota Press, 1984), 6. In the Upanișads, however, a single voice expresses not an individual consciousness or personality, but rather a different standpoint on some aspect of reality.

3 The division of Aryan tribal society into rival phratries may account for the agonistic narratives of Aryan mythology and in Indian epic; see Yaroslav Vasilkov, Mif, ritual iistoria v "Mahabharate" (St. Petersburg: Evropeyskiye issledovaniya, 2010), 98-111.

4 Franciscus Kuiper, “The Ancient Aryan Verbal Contest," Indo-Iranian Journal 4 (1960): 238, 264-274.

5 Kuiper, "The Ancient Aryan Verbal Contest," 279.

6 Johannes Cornelis Heesterman, "Brahmin, Ritual and Renouncer," Wiener Zeitschrift für die Kunde Süd- und Ostasiens 8 (1964): 1-31.

7 Calvert Watkins, How to Kill a Dragon: Aspects of Indo-European Poetics (Oxford: Oxford University Press, 1995), 70.

8 Louis Renou, “Le Passage des Brahmaṇa aux Upanișad," Journal of the American Oriental Society 73, no. 3 (1953): 141. 
brahmodyas can be found in late sūktas of the Rgveda (ṚV) (e.g. I.168, X.129), and there is a number of them in the Brāhmanas. In comparison with ancient verbal contests, the classic riddle-type brahmodya is less agonistic: it is not a real contest, but a formal exchange of riddles and answers with a fixed form and contents. The participants of such a performance would have been priests, but not necessarily poets.

A well-known example of brahmodya can be found in the Vājasaneyi Saṃhitā (VS 23.9-10):

Who travels alone?

And who is born again?

What is the remedy for cold?

What is the big bowl?

The sun travels alone.

The moon is born again.

Fire is the remedy for cold.

The earth is the big bowl. ${ }^{9}$

Brahmodyas of this kind are tautological, as the question here is identical to its answer. ${ }^{10}$ These riddles were evidently not intended for gaining new information. Thompson has proposed they were probably connected with the Vedic practice of secret names (gúhya a nâmāni), belonging to the poetic/esoteric language of the rșis and initially of the gods. ${ }^{11}$ The gods, in accordance with the Brāhmanic saying, are fond of the hidden and dislike the obvious. ${ }^{12}$ In the poetic language of the Vedas, there are sets of synonyms to substitute words from ordinary language. This diglossia of ordinary and poetic language was not uncommon even in other ancient Indo-European cultures. Generally characterized

\footnotetext{
9 káh svid ekākí carati ká u svij jāyate púnaḥ /

kịm svid dhimásya bheșajám kịm u āvápanaṃ mahát //

sủrya ekākí carati candrámā jāyate púnah /

agnîr himásya bheșajám bhümir āvápanaṃ mahát //

Albrecht Weber, ed., The Vājasaneyi-Saṃhitā in the Mādhyandina and Kānva-Śākhā with the Commentary of Mahidhara (Varanasi: Chowkhamba, 1972), 711. All the translations with the Sanskrit text in the footnotes are mine. In other cases, the name of the author of the translation is provided.

10 Tatyana Elizarenkova and Vladimir Toporov, "O vediyskoy zagadke tipa brahmodya," in Paremiologicheskiye issledovaniya, ed. Grigiriy Permyakov (Moscow: Nauka, 1984), 16-19.

11 George Thompson, "The Brahmodya and Vedic Discourse," Journal of the American Oriental Society 117 (1997), 15-16.

12 parokșakāmā hi devāḥ; cf. Charles Malamoud, "The Gods Have No Shadows: Reflections on the Secret Language of the Gods in Ancient India," in Cooking the World: Ritual and Thought in Ancient India, trans. David White (Delhi: Oxford University Press, 1996), 195-206.
} 
as the opposition of the "language of the gods" and the "language of men," in some cases it appears to be an elaborate hierarchy of languages belonging to other types of beings. ${ }^{13}$ The use of secret names instead of ordinary ones may indicate the transfer from ordinary reality to the sacral sphere of ritual. Thus the abovementioned brahmodyas can be considered a kind of glossary for a secret lexicon that might have looked something like this:

1. $\operatorname{sun}=[$ he who $]$ travels alone;

2. $\operatorname{moon}=[$ he who] is born again;

3. $\quad$ fire = remedy for cold;

4. earth $=$ big bowl.

The description introduced in the interrogative part of the brahmodya is the "secret" counterpart of the word from ordinary language in the answer. Questions in brahmodyas are intended to test whether the person questioned knows the "secret speech." "At the same time, the agonistic nature of these dialogues must not be overestimated: the examination was quite formal, because the participants knew the questions and answers in advance. ${ }^{15}$

\subsection{Brahmodyas without Answers}

The "classical" brahmodya is a question with an answer. In a broader sense, however, this term is used with respect to questions without answers, and enigmatic passages that concern secret knowledge that should not be articulated or explained in an explicit manner. Over the course of time, the genre of brahmodya changed significantly, with interpretation becoming even more problematic. Some enigmatic passages cannot be interpreted unambiguously, either by traditional commentators or by modern scholars.

A transitional type between the riddlelike brahmodyas and enigmatic passages are those brahmodyas containing questions without an explicit answer. In these brahmodyas, the person questioned just pledges to know the answer

13 Tatyana Elizarenkova and Vladimir Toporov, "Drevneindiyskaya poetika i ee indoevrioeyskiye istoki," in Literatura i kultura drevney i srednevekovoy Indii, eds. Georgiy Zograf and Vladimir Erman (Moscow, Nauka: 1979), 43-52; Watkins, How to Kill a Dragon, 38, 269.

14 Thompson, "The Brahmodya and Vedic Discourse," 15-16.

15 Johannes Cornelis Heesterman, "On the Origin of the Nāstika," Zeitschrift für die Kunde Süd- und Ostasiens 12-13 (1968-69): 172-177. 
that most probably belongs to the realm of secret inexpressible knowledge. This type is exemplified in this dialogue in VS 23.59-60:

Who knows the navel of this world?

Who [knows] heaven and earth and the intermediate space? [. . .]

I know the navel of the world.

I know heaven and earth and the intermediate space. ${ }^{16}$

Brahmodyas of this kind can be compared with the Vedic practice of satyakriy $\bar{a}$, i.e. acts of uttering truth, where the truthfulness of the speech act allows the speaker to attain supernatural results. ${ }^{17}$ The accent on the personal power of the speaker, rather than on the content of the answer, can be considered a premise to the transfer from the "physical" ritual performed by different priests to the internalized "mental" ritual performed by a single priest in his own mind. ${ }^{18}$

This tendency to transfer the ritual performance from the physical realm to the mental one can clearly be traced in later Vedic texts. For example, it influenced the narrative structure of RV X.129 (the "Nāsadìyasūkta"). This hymn has been composed as an answer to the ultimate question: what existed in the very beginning, when there was nothing - when neither the nonexistent nor the existent existed? ${ }^{19}$ The verses of the hymn do not provide a single solution; instead, different hypotheses are specified: were there waters (RV X.129.1)? Was there breathing (RV X.129.2), heat (RV X.129.3), or desire (ṚV X.129.4)? The set of questions concludes with the claim that the connection between existent and nonexistent was discovered by wise men/poets in their own hearts by means of intuition..$^{20}$ Different options are reported to represent the variety of possible explanations for the origin of the universe that existed at the time. None of them is satisfactory; still, none of them is explicitly refuted. Taken all together, they contribute to the polyphonic character of the Nāsadìyasūkta.

Brereton underlines the importance of the narrative structure of this hymn, which, he claims, makes the audience understand that the true origin of the universe is thought or the process of thinking:

By making its listeners reflect, the hymn causes them to recover the fundamental creative principle, thought itself. It does not offer a detailed picture of the origin of things nor

16 kó asyá veda bhúvanasya nắbhiṃ kó dyấvāpṛthiví antárikṣaṃ [. . . ] védāhám asya bhúvanasya nấbhim véda dyấvāprthiví antárikṣaṃ

(Weber, Vājasaneyi-Saṃhitā, 730).

17 Thompson, "The Brahmodya and Vedic Discourse," 19.

18 Heesterman, "On the Origin of the Nāstika," 177.

19 nấsad āsīn nó sád āsīt tadầnīm (ṚV X.129.1a).

20 hṛ̂î pratîṣyā kaváyo manīṣă (ṚV X.129.4d). 
describe the nature or agent of primordial thought, because to do so would defeat its own purposes. For if its function is to create thinking through questioning, then the poem must avoid a final resolution which would bring an end to questioning and an end to thought. Just as the poem begins with something between existent and non-existent, it must leave its readers between knowledge and ignorance. Thus, the openness of the poem points to the process of thinking as an approximate answer to the unanswerable riddle about the origin of things. ${ }^{21}$

This open-endedness and the lack of an explicit answer in this hymn can be considered an example of the shift from the externalized/objective to the internalized/subjective paradigm of thought and action.

Another interpretation was proposed by Thompson, who suggested that enigmatic passages of the Rgveda avoid explicit answers and interrogative forms due to "poetic, rather than hermeneutic, intent," as the Rgveda, "unlike the more hermeneutical Brāhmaṇas," is "a highly poetic text." 22 It seems, however, that the pragmatic aspect of Vedic passages must be taken into account. Even if the interchange of questions without answers served poetic purposes, still the very practice of their utterance remained a kind of communication intended for information exchange. Compared to the verbal contests of the previous period, these dialogues had lost their agonistic features but remained a form of interaction, with a gradual shift from communication between different participants to the internalized search for the secret knowledge hidden in one's own heart.

\section{3 "Enigmatic" Brahmodyas}

To even less agonistic brahmodyas belong the enigmatic passages of the Vedas, which do not contain explicit questions and as such cannot be designated as riddles. Despite their neutral, nonagonistic form, brahmodyas of this type are still challenging, since their meaning is quite incomprehensible. The most striking example of this type of brahmodya is the verses of R.V I.164. This unusually long sūkta (52 verses) is well-known as the "Riddle Hymn", as it contains a series of enigmatic verses, the interpretation of which has baffled both traditional commentators as well as modern scholars. ${ }^{23}$ In the first verse of the hymn,

21 Joel P. Brereton, “Edifying Puzzlement: Rgveda 10. 129 and the Uses of Enigma,” Journal of the American Oriental Society 119, no. 2 (1999), 258.

22 Thompson, "The Brahmodya and Vedic Discourse," 22.

23 For the survey of available interpretations, cf. Jan E. M. Houben, "The Ritual Pragmatics of a Vedic Hymn: The 'Riddle Hymn' and the Pravargya Ritual,” Journal of the American Oriental Society 120, no. 4 (2000): 499-536. 
three brothers are enumerated: the old hotr priest, his ravenous middle brother, and the third brother, who has ghee on his back. This verse has been subject to numerous interpretations. According to Sāyana, the three brothers are the sun, wind, and sacrificial fire; Haug has suggested they are the celestial fire (sun), fire of the intermediate space (lightning), and terrestrial (sacrificial) fire; Geldner has claimed that the verse speaks about three sacrificial fires (ähavaniya, dakșināgni, gārhapatya).${ }^{24}$ Some other verses are less problematic. For example, RV I.164.11 concerns the wheel of $r t a$, with twelve spokes and 720 sons standing on it in pairs. Most probably, the wheel can be interpreted as the sun, whose yearly cycle lasts twelve months, whereas the 720 sons standing in pairs refer to the 360 days and 360 nights comprising a year. ${ }^{25}$ Disagreements also arise with respect to other verses. The well-known passage R V I.164 20-22, which describes two birds sitting on a tree and either eating or refraining from eating a fruit, has been interpreted in radically different ways: ranging from Śankara's interpretation of the birds as souls creating karma or releasing from it, ${ }^{26}$ to Johnson's view of the birds as poets taking part in poetic assemblies and being either allowed or not allowed to drink soma. ${ }^{27}$

Houben has proposed a completely different interpretation of the hymn based on its ritual pragmatics. According to the Śrautasūtras, several verses of the hymn are pronounced over the course of the Pravargya ritual. The action in this ritual is generally focused around the pot (gharma), which is filled and anointed with ghee and placed on the fire. A cow and a goat are milked, and some of their milk is put into the boiling ghee in the gharma, making a pillar of fire arise from it. This central episode of Pravargya, Houben claims, correlates with the verses RV I.164.26-29:

The cow has lowed after the calf which blinks its eye. [. . .] This one is humming, by which the cow is enveloped. She lows a lowing (when she is) placed on the sparkling (fire). With her cracklings she has indeed put down the mortal. Transforming herself to lightning (vidyut), she pushed back her covering. ${ }^{28}$

These verses can be considered another example of the use of secret language. The cow enveloped by the calf, through metonymical transfer, may refer to the

24 Tatyana Elizarenkova, Rigveda: Mandaly I-IV (Moscow: Nauka, 1999), 645; Houben, “The Ritual Pragmatics of a Vedic Hymn,” 516.

25 Elizarenkova, Rigveda, 646.

26 Śankara's interpretation is indeed anachronistic, since the doctrine of karma belongs to a more recent period.

27 Willard Johnson, "On the RG Vedic Riddle of the Two Birds in the Fig Tree (RV 1.164. 20-22), and the Discovery of the Vedic Speculative Symposium," Journal of the American Oriental Society 96, no. 2 (1976): 248-258.

28 Translated by Houben (Houben, "The Ritual Pragmatics of a Vedic Hymn," 535). 
milk (cow) enclosed inside the pot (calf). It is the gharma pot, which is humming while being heated. The milk (cow), after being put into the pot full of hot ghee, crackles and "transforms to lightning." 29 Another important identification in the figurative system of the hymn is that of the gharma and the sun: the heated pot can be considered a substitute for the sun. Accordingly, the three brothers from the first verse are the fires of the three worlds: the sun/old hotr is the fire of celestial world; the third brother, with ghee on his back, is the gharma, the fire of terrestrial world; and the ravenous middle brother is probably the lightning, the fire of the intermediate space. ${ }^{30}$ The sun and the gharma pot may also be inferred from the symbolism in RV I.168.20-22, where the two birds embracing a tree - the world tree as a symbol of the unity of the universe - correspond to the sun (at the top) and gharma (at the bottom). The pot filled with ghee, a substitute for amrta, is the bird that eats the fruit, whereas the sun is the bird that watches without eating. Gharma is initially inanimate, but when heated it comes to life, and as such can be compared with the mortal person that partakes in the secret knowledge or attains the immortality associated with the sun. ${ }^{31}$

All these interpretations are indeed hypothetical, being based on different presuppositions. And we should not forget that they are not necessarily mutually exclusive. From the tradition of the Brāhmanas onwards, three different modes of interpretation of a Vedic passage have been accepted, depending on the intention of the interpreter: adhyātma (referring to the self), adhiyajña (referring to the sacrifice), and adhidaiva (referring to the deities or the cosmos). ${ }^{32}$ Thus, it can be assumed that one and the same passage could intentionally be left open to different interpretations. From a semiotic perspective, brahmodya is a practice of dealing with symbols that join together different levels of description. A "tautological" brahmodya that sets up correspondences between the pairs of the utterances belonging to ordinary and secret speech can be characterized as a structure of a single signified aspect (meaning) and two signifiers. On the contrary, enigmatic brahmodyas, which have several different modes of interpretation, are structures combining one utterance (signifier) with several signified aspects.

29 Houben, "The Ritual Pragmatics of a Vedic Hymn," 504-507.

30 Houben, "Ritual Pragmatics," 516-518. The use of the epithet "ravenous" (áśna) with respect to lightning remains problematic. Houben suggests a connection with the fierce and voracious character of Indra, "the god of thunder."

31 Houben, "Ritual Pragmatics," 520-522.

32 Cf. Michael Witzel, On Magical Thought in the Veda (Inaugural Address, Leiden University) (Leiden: Universitaire Pers Leiden, 1979), 8, 18. 
Brahmodya can be considered an early stage in the development of a tradition of public communication. Derived from the agonistic poetic contests, it took shape in the ritualized exchange of riddle-type questions and answers, as well as in enigmatic passages in which the questions are always implicit. However, even the latter type of brahmodyas was intended to transmit some information, and as such can be considered a kind of communicative practice. Some brahmodyas may very likely be interpreted in the context of ritual pragmatics, and some may refer to cosmological doctrines or the secret knowledge of the self. This understanding of the form and function of brahmodyas does not align with Thompson's argument, namely that enigmatic brahmodyas were motivated by "poetic, rather than hermeneutic, intent." 33 Indeed, it can be assumed that Vedic rșis, like Vedic gods, "were fond of the hidden and disliked the obvious," 34 but it is also plausible that they really wanted to convey information that for some reason was not to be expressed in an unambiguous manner. The form of the brahmodya challenged the audience, yet this challenge did not imply agonistic confrontation, but rather something like a shift of paradigm.

Brahmodyas of the enigmatic type are also distinctive in that they do not presuppose that there must be a single point of view. The admission of the diversity of interpretation, each being justified in a certain context, can originate from the functional attitude of Vedic ritualism. In any case, brahmodyas can be considered as an early example of nonagonistic - or not entirely agonistic communication practices in ancient Indian texts.

\section{Intellectual Confrontation in the Early Upaniṣads}

\subsection{Brahmodyas in the Upanișads}

The early Upanișads are considered a part of the Vedic canon, and these texts share common features with some earlier Vedic texts, particularly the Brāhmanas. These shared features are clearly evident in the old prose Upanișads, containing extensive intellectual debates - the Bṛhadāraṇyaka (BAU) and Chāndogya (ChU) Upanișads. In this section I will not focus on the philosophical, ritual, or religious ideas expressed in the dialogues of the early Upanișads; instead, I will consider

33 Thompson, “The Brahmodya and Vedic Discourse," 22.

34 Cf. fn. 13. 
these dialogues as cases of intellectual confrontation, analyzing the rules and shared presuppositions on which the communication of the different parties is based. My analysis emphasizes the parallels between the dialogues of the Upanișads and the earlier Vedic brahmodyas. In addition, I will outline the features of their subsequent evolution: from formal, fixed brahmodyas to looser agonistic debates, and from exchanges between anonymous interlocutors to personified teacher-pupil relations.

The classic riddle type of brahmodya is not at all alien to the Upanisads. BAU II.2 contains an example of an explicit brahmodya:

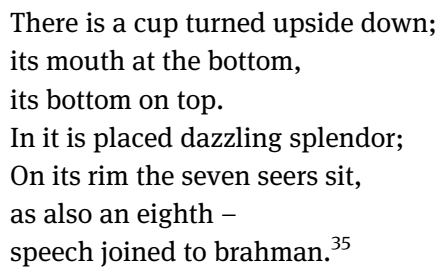

Immediately after this verse comes the explanation: the bowl is the head, the seven rṣis are the prānas, etc. Still, brahmodyas of this kind are not very common at this stage. The typical brahmodyas of the Upanișads differ significantly from the enigmatic and riddle-type brahmodyas of the Vedas and Brāhmaṇas. These are vivid dialogues on ritual and philosophical matters held by participants, each possessing a name and an implicit or explicit personal history. The dialogues are of an agonistic nature and as such are closer to ancient Indo-European verbal contests than to the fixed brahmodyas of Brāhmanic ritual. At the same time, it would be too straightforward to consider the Upanișadic brahmodyas to be the immediate predecessors of the classical philosophical $v \bar{a} d a$. The agonistic and nonagonistic features of these disputes in the Upanișads demand closer consideration.

The dialogues of the early prose Upanișads can be generally divided into two types: debates and instructions. The agonistic nature of the debates is evident from the very exposition of the circumstances in which they take place. For example, as we learn at the outset of the dispute between Yājñavalkya and other priests (BAU III.1):

Janaka, the king of Videha, once set out to perform a sacrifice at which he intended to give lavish gifts to the officiating priests. Brahmins from the Kuru and Pañcāla regions had flocked there for the occasion, and Janaka of Videha wanted to find out which of those Brahmins was the most learned in the Vedas.

35 Translated in Patrick Olivelle, The Early Upanishads: Annotated Text and Translation (Oxford: Oxford University Press, 1998), 65. 
So he corralled a thousand cows; to the horns of each cow were tied ten pieces of gold.

He then addressed those Brahmins: "Distinguished Brahmins! Let the most learned man among you drive away these cows." But those Brahmins did not dare.

So Yājñavalkya called to his pupil: "Sāmaśravas! Son, drive these cows away.” And he drove them away. The Brahmins were furious and murmured: "How dare he claim to be the most learned?"36

In what follows, the adversaries ask Yājñavalkya various challenging questions; he gives answers, poses questions to each of his opponents in turn, and eventually claims victory.

Generally, the participants of Upanișadic brahmodyas - wise men (and also women), brahmins, and kșatriyas - engage in verbal contests in order to prove the superiority of their own knowledge and (in the case of the brahmins) to receive cows, gold, and other wealth as a prize for the winner. As a rule, the loser becomes the pupil of the winner, and in some cases, he is also threatened with losing his head. No wonder, as initially, brahmodya was a part of a ritual in which a single mistake in performance - even an incorrect accent in a word of a mantra - could have devastating consequences for the priest as well as for the sacrificer. ${ }^{37} \mathrm{~A}$ formal way of acknowledging defeat was to fall silent.

\subsection{The Structure of Upanișadic Brahmodyas}

At the same time, the agonistic tendencies in Upanișadic debates should not be overestimated. Agonistic disputes between brahmins and other wise people might have been practiced in India in the middle of the first millenium BCE. Still, the question may arise whether the early prose Upanișads depict this practice literally. This is not a question of whether "the Upanishadic brahmodyas record real events," 38 but rather, of whether we may identify the practices described in the texts with the actual practices of the debates that took place in India at that time. Obviously, both have much in common, with the literary descriptions following actual practice in a certain way. However, we should not forget that the Upanișads were composed and edited over a long duration and, as a result, were texts of deliberate composition.

36 Translated in Olivelle, The Early Upanishads, 75.

37 Cf. the well-known story from the Śatapatha Brāhmaṇa $(\mathrm{I} .6 .3 .8,10)$ about Tvașț̣ mispronouncing the accent in a word of a mantra.

38 Brian Black, The Character of the Self in Ancient India: Priests, Kings, and Women in the Early Upanishads (Albany: State University of New York Press, 2007), 60. 
This is especially true in the case of the BAU. Brereton has argued against the widespread view that this Upanișad is "a loosely structured collection of assertions, observations and aphorisms about the nature of things" that can be interpreted as "gathering together the diffuse passages in which certain terms or themes occur and then constructing out of them a synthesis or even a system." ${ }^{39}$ He has suggested interpreting the passage in BAU III as a highly structured textual unit, since its formal composition recalls the ring composition of a typical Vedic sacrifice in which the end recapitulates the beginning. In BAU III, this recapitulation is accomplished by means of a frame story. Moreover, Brereton demonstrates that there are many cases of double narrative episodes (two gandharva dialogues, two conversations with Gārgī) and of thematic double repetitions (questions concerning one's fate after death, the principles that underlie the worlds, the nature of Brahman). ${ }^{40}$ This interpretation was supported by Hock, who suggested that the passage in BAU III can be viewed as part of the larger ring composition of BAU II.1-4.5. ${ }^{41}$

Along with the general structure of the passages, it seems reasonable to focus on the form and content of certain dialogues. Although according to the frame story, these dialogues occur within an agonistic debate, they appear to be scripted rather than spontaneous. For example, BAU II.1 recalls a dispute between the brahmin Dṛpta-Bālāki Gārgya and the king Ajātaśatru. DṛptaBālāki articulates twelve propositions for the location of the puruṣa that he venerates $^{42}$ as Brahman: sun, moon, lightning, space, wind, fire, waters, mirror, sound drifting behind the moving one (echo), directions, shadow, and the Self (Ātman). Ajātaśatru refutes every proposition, in each case providing a different description for each location: he venerates the sun as preeminent, the head and the king; the moon as the great king Soma in a white dress, etc. Eventually, Dṛpta-Bālāki falls silent, recognizing his defeat, and asks permission to become Ajātaśatru's pupil. After, Ajātaśatru reveals the secret teaching of prāna as the true basis of the puruṣa, which consists of cognition (vijñānamaya) and as such is the basis of all cognitive functions.

39 Joel P. Brereton, “'Why Is a Sleeping Dog Like the Vedic Sacrifice?': The Structure of an Upanișadic Brahmodya," in Inside the Texts, Beyond the Texts: New Approaches to the Study of the Vedas, ed. Michael Witzel (Cambridge: Department of Sanskrit and Indian Studies, Harvard University, 1997), 3.

40 Brereton, “Sleeping Dog," 3.

41 Hans Henrich Hock, “The Yājñavalkya Cycle in the Bụhadāraṇyaka Upaniṣad,” Journal of the American Oriental Society 122, no. 2 (2002): 278-286.

42 On the semantics of the verb upās (worship as a contemplation practice), cf. Vsevolod Sementsov, Problemy interpretatsii brahmanicheskoy prozy (Moscow: Nauka, 1981), 12. 
One can hardly consider the twelve options formulated by Dṛpta-Bālāki as spontaneous arguments in an agonistic dispute. His statements are uniform and monotonous, and the same can be said of Ajātaśatru's objections. None of the disputants rationally justifies his views, but only proposes different descriptions. At the same time, Dṛpta-Bālāki's arguments as a whole provide quite a comprehensive list of important natural phenomena. He enumerates the three sources of light (sun, moon, lightning), five primary elements (space, wind, fire, waters, direction), and some other natural phenomena (echo, reflection, shadow) that may seem enigmatic. It can be assumed that this list is not arbitrary. On the contrary, it can be viewed as a deliberate enumeration of possible views on the nature of puruṣa and/or of the constituent parts of the world. Indeed, Dṛpta-Bālāki's statements do not represent an elaborate nature-philosophical system, but they do catalogue relevant elements of the universe.

The same may be true for certain other sets of statements or questions. In BAU III.6, Gārgī Vācaknavī questions Yājñavalkya's understanding of the basis on which the world is "woven." Each answer he provides prompts a further question from her. From Yājñavalkya's answers, we learn that the world is woven on waters; the waters in turn on wind/air; wind/ air on the worlds of the intermediate space; the worlds of the intermediate space on the worlds of gandharvas, etc. With respect to this dialogue, Brereton notes, "These worlds through which the dialogue progresses mark the path to heaven, as the description of the way to heaven in Kauśitaki Upanișad shows."43

Moreover, in ChU V.11-17, the king Aśvapati instructs the householders, asking them one by one what they venerate as the Self (Ätman). They give various answers (sky, sun, wind, space, waters, and earth), and each time Aśvapati objects that it is not Âtman, but only one of its aspects (eye, breath, body, bladder, and feet). Again, this dialogue is not a sequence of arbitrary standpoints. On the contrary, it presents a systematic description of the universe on both the macro- and microcosmic levels.

Each set of questions of this type is generally focused on a single theme, with the traditional distinction between the adhyātma, adhiyajña, and adhidaiva levels being observed. For example, in BAU III.1, the brahmins question Yājñavalkya about sacrificial issues (adhiyajña); BAU III.2 addresses cognitive functions (grahas and atigrahas), ${ }^{44}$ an adhyātma topic (the same is true of BAU IV.1); and BAU III.9 concerns adhidaiva.

43 Brereton, "Sleeping Dog," 11.

44 On grahas and atigrahas, cf. Brereton, “Why Is a Sleeping Dog Like the Vedic Sacrifice?” 7. 
The Upanișadic dialogues cannot be considered merely a depiction of an exchange of arguments in an agonistic dispute. Given the deliberate structure of the dialogues of the Upanișads, it can be supposed that dialogue is just a textual form intentionally adopted as a means of narration. The structure of the dialogue provides a comprehensive description of a certain topic, with each statement corresponding to a certain aspect of the object described. The adoption of this genre reflects the tendency of Brahmanic discourse to consider each problem from different perspectives, polyphonically combining different views in the frame of a single doctrine.

\subsection{Means of Justification: Rational vs. Intuitive}

Characteristically, the Upanișadic disputes illustrate no process of rational justification. The pattern of the classical brahmodya implies that for each question, there must exist only one right answer. In accordance with this, in every Upanișadic dialogue, there is a single participant who knows the right answers (Ajātaśatru in BAU II.1, Yājñavalkya in BAU III, Aśvapati in ChU V.11-17). ${ }^{45}$ This participant articulates his answers either through being questioned or objecting to someone else's statements. The latter type of discourse (BAU II.1 and ChU V. 11-17) can be considered the most agonistic; still, even there, the speaker generally does not justify his view and merely states it, somehow persuading the opponent. ${ }^{46}$ In the rare cases of rational inquiry, the speaker supports his views by means of analogy, as Yājñavalkya did in his well-known comparison of consciousness with a lump of salt (BAU II.4; IV.5). ${ }^{47}$

The Upanișadic dialogues concern secret knowledge that cannot be justified through logical argument. It is the knowledge to which one appeals in the

45 In the Brāhmaṇas, however, participants usually exchange roles in asking questions and giving proper answers, which corresponds to the archaic dualistic/cyclic pattern of exchanging roles in an agonistic contest; see Yaroslav Vasilkov, "Did East and West Really Meet in Milinda’s Questions?” Petersburg Journal of Cultural Studies 1 (1993): 66.

46 Cf. Black, The Character of the Self in Ancient India, 79: "Yājñavalkya, for example, does not necessarily win because of his wisdom, but because he knows the rules of the game, and how to break them. He knows how to convince people through his timing, humor, cryptic remarks, and as we shall see, intimidation and threats."

47 On the meaning of the comparison, cf. Walter Slaje, "Water and Salt (I): Yãjñavalkya's Saindhava Dṛ̣tānta (BĀU II 4, 12)," Indo-Iranian Journal 44 (2001): 25-57. 
course of satyakriy $\bar{a}^{48}$ or in Brāhmanic brahmodyas that does not imply an explicit answer; ${ }^{49}$ the secret knowledge repeatedly referred to in the Brāhmanas by the formula ya evam veda ("he [who] knows this"). ${ }^{50}$ This knowledge may somehow change the appearance of the person: after gaining such knowledge, both Satyakāma and Upakosala started shining "as the one who knows Brahman" (ChU IV.10, 14). But if someone's claim to possessing this kind of knowledge is ill-founded, the consequences will be devastating: his head will shatter in pieces as happened to Sākalya, who was unable to answer Yājñavalkya's question. ${ }^{51}$ Notably, even Yājñavalkya is threatened that his head will shatter in pieces when he insists that he knows the answer without explicitly saying it (BAU III.7). But again, this refers to providing the answer, not to justifying it.

At the same time, it is not unusual that a question should not be answered aloud or explicitly. In BAU III.2, Yãjñavalkya refuses to answer the most secret question in public, and the only thing we know from the text is that he taught about action (karma). ${ }^{52}$ In other cases, the explication of the knowledge itself can be problematic, because it is evidently not the knowledge of linguistic formulas, but some intuitive nondiscursive information that the speaker wishes to express. This is true in the case of Yãjñavalkya's teaching of the Self (Ātman) as something that cannot be categorized. Yājñavalkya's intention is to make his interlocutors experience their own Self in a nondiscursive way. For this reason, he does not talk about the Self in general, but tries to "show" the opponent his own Self ("your Atman"). He insists that the Self is the basis of all cognitive processes and blames Sākalya for believing that Âtman is somewhere else, but not in him (BAU III.9.25).

48 Acts of uttering truth, in which the truthfulness of the speech acts allows the speaker to attain supernatural results. For details, cf. Thompson, “The Brahmodya and Vedic Discourse," 19.

49 Cf. section 1.2.

50 Sementsov, Problemy interpretatsii brahmanicheskoy prozy, 27-46.

51 On the phenomenon of the head splitting apart, cf. Black, The Character of the Self in Ancient India, 65, 80, 185.

52 Black interprets Yājñavalkya's refusal to speak in public as "a rather unusual method to silence his opponent," and supposes that Yājñavalkya's opponent had caught him in a contradiction (Black, Character of the Self, 76-77). Similarly, referring to conversations with gandharvas, Black suggests that the actual participants in the talk were females, but the male interlocutors totally denied their agency and attributed their words to gandharvas (Black, Character of the Self, 171) A modern reader could indeed discredit the existence of secret knowledge and gandhar$v a s$, but there is no doubt that the authors of ancient texts could have held another opinion. A positive attitude towards the supernatural phenomena described in the Upanișads is justified if we consider these texts a depiction of historical events. However, in a study of the worldview of the people of premodern India, positive criticism may appear redundant. 
This kind of argument may have been unusual for the prevalent scholastic discourse at that time. For example, Ușasta Cākrāyana protests against the ostensive definitions (i.e. defining by pointing out examples) of Brahman and Ātman, which, he claims, are similar to pointing and uttering, "This is the cow and that is the horse." 53 Yājñavalkya objects that it is impossible to objectify and define something that is the basis of all cognitive processes. It is impossible to see the seer who sees, to hear the hearer who hears, to think of the thinker who thinks, to cognize the cognizer who cognizes (BAU III.4). ${ }^{54}$

Thus, verbal agonism in Upanișadic disputes was not a competition in logical debate. Such disputes were rather based on secret intuitive knowledge, which was the main criterion for the validity of verbal utterances. Participants in these disputes could only demonstrate in some nondiscursive manner that they possess this knowledge and win - or lose (and even lose their heads) if their claims were invalid.

\subsection{From Agonistic Dialogues to Teacher-Pupil Discourse}

In the dialogues of the early prose Upanișads, two general types can be distinguished: agonistic disputes between brahmins, or brahmins and kṣatriyas, and the instruction of a pupil by a teacher. Teacher-pupil relations were indeed important in the discourse of the Upanișads. Generally, in BAU, the majority of the dialogues are of the agonistic type, whereas in ChU, instruction prevails. However, in some cases, agonistic disputes end up as instruction, as the participant who loses a dispute becomes the pupil of the winner. In BAU II.1 and III.2, after their opponents recognize defeat, Ajātaśatru and Yājñavalkya take their hands. This gesture is usually associated with upanayana, meaning that they initiate their opponents as pupils. ${ }^{55}$ Only after that do they instruct their former rivals in secret teachings (in the case of Yãjñavalkya, this teaching is not to be explicated in public). Similarly, in BAU VI.2, Gautama asks Jaivali Pravāhaṇa to answer the questions that Jaivali had previously posed to Gautama's son, but Jaivali refuses to teach him unless Gautama declares himself his pupil. ${ }^{56}$

53 asau gaur-asāv-aśva iti.

54 na dṛșter-drașṭāram paśyeḥ. na śruteh ṣrotāraṃ śṛ̣uyāḥ. na mater-mantāraṃ manvīthāḥ. na vijñāter-vijñātāraṃ vijānīyāḥ.

55 Black, The Character of the Self in Ancient India, 77.

56 Similarly, in the Milindapañha (a work far removed from Vedic tradition), the king Milinda, after his defeat in the contest, moves to a deserted place together with Nāgasena, which might 
Secret knowledge can be requested as a boon by a pupil (BAU IV.3). Alternatively, one may offer gifts to a teacher in order to become his pupil, as in the case of Jānaśruti, who offered Raikva hundreds of cows, gold, a vehicle, and, last but not least, his own daughter as a wife (ChU IV.2). But becoming a pupil does not guarantee receiving instruction. Prajāpati tried to deceive his pupils with false teachings (ChU VIII.7-12). Satyakāma Jābāla spent several years looking after his teacher's cows, and only once they numbered one thousand was he instructed: at first, by animals and fire, and only after that, by the teacher (ChU IV.4-9). Satyakāma, in turn, did not instruct his pupil Upakosala, who spent twelve years after upanayana keeping the sacrificial fires burning; only after Upakosala abstained from eating did he receive instruction from the fires (ChU IV.10-14). Both stories probably refer to a kind of trial that a pupil must pass through, becoming fit to receive knowledge. It was fitness of a supernatural kind that enabled them to receive instruction from natural phenomena.

Notably, in the Upanișads, instruction is usually received when a pupil is in some kind of stress. ${ }^{57}$ Examples of such distressed parties are unsuccessful disputants whose views have been refuted; Maitreyī, whose husband is going to leave her (BAU II.4; IV.5); Śvetaketu, who is unable to answer his father's question after twelve years of study (ChU VI.1); and Naciketas, cursed by his own father and facing Yama, the god of death (Kațha Upanișad). It can be assumed that irrational nondiscursive knowledge of the Upanișads is to be comprehended by someone who suddenly becomes confused: whose former convictions and beliefs turn out to be invalid. In the narrative logic of the text, the agonistic dispute becomes just a preliminary episode that precedes instruction. The outcome of a real dispute is indeed unpredictable. But it is a written cliché in the Upanișads and some other texts that a potential pupil engages in a dispute with his future teacher and loses, giving the author of the text the opportunity to transmit his teaching. ${ }^{58}$

In summary, the brahmodya dialogues of the Upanișads are very diverse, as they represent different kinds of social interactions: from agonistic disputes to instructional tutorials. The participants of the dialogues possess names and personal history, and (contrary to the Brāhmanic tradition of the ritualized, cyclic exchange of questions) their contests end in victory or defeat. The validity of the statements

imply the practice of receiving instruction from the teacher. On the parallels between the structure of the archaic brahmodya and disputes in the Milindapañha, cf. Vasilkov 1993.

57 I thank Dr. Paribok for this observation.

58 This narrative device is quite common in Pali suttas. In the Payasi-sutta, at the end of the dispute, Payasi admits that he was convinced by the very first parable of Kassapa, but continued to object, as he wanted to hear more of Kassapa's answers. 
in Upaniṣadic contests is usually justified not by means of rational argument, but through the charisma of the participant and his association with nondiscursive knowledge. At the same time, the agonistic features of brahmodyas in the early prose Upanișads should not be overestimated, as these texts are distinguished by their deliberate composition, in the frames of which verbal contests can be considered a narrative device, adopted by anonymous authors in order to express certain views and teachings.

\section{Nonagonistic Discussions in the Mahābhāṣya}

\subsection{Dialogues in the Mahābhāṣya}

Patañjali's Mahābhāșya (2nd century BCE) is a work that occupies an intermediate spot between Vedic texts and Sāstric philosophical discourse. The Indian grammatical tradition (vyākaraṇa) that this text belongs to was initially an auxiliary Vedic discipline (vedāinga), intended to ensure correct linguistic usage in the course of ritual. Pāṇini's Aștāahyāyī (fifth to sixth century BCE), the fundamental text of this tradition, went far beyond this practical purpose by providing a comprehensive description of Sanskrit based on an elaborate technique of linguistic analysis. The Mahābhāșya $(M B h)$, the foundational commentary on the Aștāadhyāȳ, is generally concerned with linguistic problems. Still, it reveals certain affinities with Vedic ritualism as well as with later philosophical discourse. ${ }^{59}$ In this section, I will analyze the dialogues in the introductory chapter of the $M B h$ (the "Paspaśā"), aiming to reveal structural similarities with Brāhmaṇic brahmodyas and Upanișadic disputes.

The $M B h$ is composed as a dialogue that echoes the discussion between a teacher and his pupils. Later on, this narrative form becomes typical of the commentary genre. The participants in a dialogue are generally anonymous, but their competence varies from that of a beginner to a more experienced speaker, and, finally, of an expert (Patañjali?), whose words are marked with ity-āha ("he said"). Discussing different grammatical and philosophical problems, speakers apply processes of rational inquiry or support their statements

59 The relation of the $M B h$ with Vedic ritualism is evident in the discussion of the aims of grammar in the introductory chapter (the "Paspaśā"). Evidence of śāstric discourse in the $M B h$ has recently been discussed in Émilie Aussant, "Vyākarạ̣ic Texts and Sāstric Discourse," The Journal of Value Inquiry 49, no. 4 (2015): 551-566. 
by relying on authoritative opinion (quotations from the Vedas, opinions of the grammarians of the past). The dialogues are quite vivid. Speakers question why should one study grammar rather than learning words and phrases of ordinary language by heart. They also cite verses of uncertain origin and suspicious content. ${ }^{60}$ In this section, I will analyze the structure of the conversations in the two passages of $M B h$ : the definition of the word, and the discussion of Kātyāyana's vārttika: siddhe śabdārthasambandhe ("word, referent, and relation [between them] being permanent [...]"). ${ }^{61}$ My intention here is to demonstrate that the discursive structure of these passages generally follows a pattern similar to that found in the Vedic and Upanișadic texts discussed in the previous sections. The use of the dialogue form is adopted here not as a literary depiction of an actual act of communication, but rather as a means to illustrate different perspectives on a problem.

\subsection{Definition of the Word in the "Paspaśā"}

The $M B h$ begins with the claim that this text contains instruction concerning words. After that, the expected question arises: what is a word?

\footnotetext{
"Now [I pronounce the word] 'cow'; what is the word [here]? ${ }^{62}$ Is the word that which possesses a form endowed with dewlap, tail, hump, hooves, and horns?"

"No," he said, ${ }^{63}$ "That is called material (dravya)."64

"Then, is the word that moving, stirring, twinkling?"

"No," he said, "That is called action (kriyā)."

"Then, is the word that white, dark, black, red, or gray?"

"No," he said, "That is called quality (guna)."

"Then, is the word that [which is] nondifferent in the differentiated, nondestroyable in destroyable, something general?"

"No," he said, "That is called universal shape (ākrti)."

"What is the word, then?"
}

60 As in the case of the pramattagita; see Franz Kielhorn, ed., The Vyākaraṇa-Mahābhāșya of Patañjali, vol. 1 (Bombay: Government Central Book Depot, 1880), 3.

61 This is a provisional translation. In section 3.3, the translation of the vārttika will be discussed in more detail.

62 This way of reasoning is indeed similar to Yājñavalkya's ostensive definition of Ātman in BAU III.4.

63 The words "ity-āha" mark the most authoritative opinion, probably that of Patañjali.

64 The meaning of the term dravya in different contexts varies from individual thing to the material of which the thing is made (substance). Later, as we will see, Patañjali intentionally plays with these meanings. 
"The word is that from which, being uttered, the image of the object possessing a dewlap, tail, hump, hooves, and horns arises in mind. Or the word is the sound whose meaning is well-known among people." ${ }^{\prime 5}$

The definition of a word, as introduced in this passage, seems quite comprehensive, but the full dialogue leaves readers a bit confused. It is hard to assume that someone would really suppose a word to be identical with the material object it describes, or with certain actions, qualities, or a general/universal form. For the same reason, it is also unlikely that these assumptions express the views of some other school of grammar. Thus, most probably, these assumptions do not depict an actual conversation of the agonistic type or a dialogue between a teacher and his pupils.

At the same time, the parallels between the concepts mentioned in this dialogue and the four padārthas of Vaiśeșika - dravya, guṇa, karma, and sāmānya are quite obvious. ${ }^{66}$ In sum, the four concepts used in the dialogue provide a framework for the description of the nonlinguistic reality the words refer to, as in order to define the word, one should also define or describe its possible referents. Thus it seems plausible that the dialogue in this passage of the $M B h$ is a narrative device by means of which this important information is conveyed. The same narrative device was applied in the Upanișadic dialogues (cf. section 2.2) for the sake of exhaustiveness of description. There is no point in supposing direct affinities between early prose Upanișads and the $M B h$. This is likely an indication that the

65

- atra gaur-ity-atra kạ̣ śabdaḥ? kị̣ yat-tat-sāsnā-lāñgūla-kakuda-khura-viṣāṇiartha-rūpaṃ sa śabdah?

- nety-āha. dravyaṃ nāma tat.

- yat-tarhi tad-ingitam ceștitam nimișitam sa śabdah?

- nety-āha. kriyā nāma sā.

- yat-tarhi tac-chuklo nīlaḥ kṛ̣ṇaḥ kapilaḥ kapota iti sa śabdaḥ?

- nety-āha. guṇo nāma sạ̣.

- yat-tarhi bhinneșv-abhinnaṃ chinneșv-achinnaṃ sāmānyabhūtaṃ sa śabdaḥ?

- nety-āha. ākṛtir-nāma sā.

- kas-tarhi śabdaḥ?

- yenoccaritena sāsnā-lāngūla-kakuda-khura-viṣāṇināṃ saṃpratyayo bhavati sa sabdaḥ. athavā pratīta-padārthako loke dhvaniḥ śabda ity-ucyate (Kielhorn, The Vyākaraṇa-Mah $\bar{a}$ bhāṣya of Patañjali, 1).

66 The $M B h$ probably predates the Vaiśeșikasūtras, though Patañjali might have been acquainted with the proponents of some proto-Vaiśeșika school (such as the "knowers of substances, qualities, and motions" (dravyaguṇakarmajña) referred to in the Mahābhārata); see Wilhelm Halbfass, On Being and What There Is: Classical Vaiśeșika and the History of Indian Ontology (New York: State University of New York Press, 1992), 75. In any case, this classification of categories is to a certain extent linguistically stipulated. 
use of a dialogue not as a depiction of an agonistic dispute, but as a narrative device intended to create a comprehensive worldview, was utilized in premodern Indian literary tradition.

\subsection{Discussion of Kātyāyana's vārttika "siddhe śabdārthasaṃbandhe"}

Kātyāyana's vārttikas are supplementary to Pāṇini's sūtras. The vārttikas were composed ca. third century BCE and exist only in the body of Patañjali's commentary. In this section, I will focus on Patañjali's commentary on the vārttika "siddhe śabdārthasambandhe." This vārttika is preceded in the "Paspaśā" by the discussion of two questions:

(1) Is the referent of the word a dravya (material thing) or ākrti (generic/universal form)?

(2) Is the word permanent (nitya) or to be produced [from the morphemes by means of grammatical procedures]) (kārya)?

Patañjali proposes nonphilosophical ("grammatical”) answers for both questions. For the first question, he admits both possibilities, as each can be supported by Pānini's sūtras. Regarding the second question, Patañjali relies on Vyādị’s Samgraha, ${ }^{67}$ where this problem has been examined with the final conclusion that, irrespective of how one may answer this question, grammatical rules should be elaborated. ${ }^{68}$

After that, the first part of the vārttika is introduced: "siddhe sabdārthasambandhe [. . .]"69 I will discuss the exact translation and interpretation of the vārttika in detail below, but it can be generally rendered as follows: "The word, referent, ${ }^{70}$ and relation [between them] being permanent [. . .]”

67 An extensive grammatical work that predates Patañjali. It was lost in the period between Patañjali and Bharț̣hari.

68 Kielhorn, The Vyākaraṇa-Mahābhāṣya of Patañjali, 6.

69 The following parts are discussed later in the "Paspaśā." The complete vārttika is: siddhe sabdārthasambandhe lokato 'rthaprayukte śabdaprayoge śāstreṇa dharmaniyamaḥ yathā laukikavaidikeșu.

70 "Referent" seems to be the most neutral equivalent for Sanskrit artha. This term, in different contexts, means "thing," "object," "meaning," “aim,” etc. In later linguistic philosophy, the meaning of artha may vary between "meaning," "thing meant," and "(external) thing”; cf. Jan E. M. Houben, The Sambandha-samuddeśa. Chapter on Relation and Bhartṛhari's Philosophy of Language (Groningen: Gonda Indological Studies, 1995), 35. Patañjali, as we will see, also 
In the extensive subsequent commentary, Patañjali proposes different ways in which the compound in the vārttika can be analyzed and discusses their philosophical implications. The passage is composed in the form of a dialogue, but it remains uncertain whether different modes of interpretation, generally introduced with the words athava "or," belong to different speakers or if they are articulated by the author of the text. In any case, this passage is of a polyphonic nature, as it comprises a number of mutually exclusive views without giving priority to any one of them.

The different opinions expressed in the passage under consideration are distinguished on the basis of the two criteria:

(a) The way in which the compound sabdārthasambandhe is analyzed: either as sabde 'rthe sambandhe ca "the word, referent, and relation [between them]" or as sabde 'rthasambandhe, "the word and its relation with the referent";

(b) The general view of the referent (whether it is dravya or $\bar{a} k r t i$ ) and the way in which the concepts of dravya and akrti are interpreted: as permanent entities (with the word siddha meaning "permanent") or as produced entities (with the word siddha meaning "accomplished").

In sum, the number of opinions discussed may be said to be five:

(1) The värttika is analyzed as siddhe śabde 'rthe sambandhe ca "the word, referent, and relation [between them] being permanent." The referent is believed to be $\bar{a} k r t i$, not dravya, since the word siddha is understood here as a synonym of nitya "permanent," and it is the universal ( $\bar{a} k r t i)$ that is permanent, not the individual material object (dravya). ${ }^{71}$

(2) The vārttika is analyzed as siddhe śabde 'rthasambandhe ca "the word and its relation with the referent being permanent." This reading does not imply that the referent per se is permanent, so in this case, the referent can be an impermanent dravya (individual material object). ${ }^{72}$

(3) The värttika is analyzed as siddhe śabde 'rthe sambandhe ca "the word, referent, and relation [between them] being permanent.” The referent is again

admitted different interpretations of artha, but in the context of the vārttika, it can be generally rendered as "referent," i.e. something to which a linguistic unit refers.

71 atha kaṃ punar padārthaṃ matvaișa vigrahạ̣ kriyate siddhe śabde 'rthe saṃbandhe ceti?

ākṛtim-ity-āha.

kuta etat?

ākṛtir-tarhi nityā dravyam-anityam (Kielhorn, The Vyākaraṇa-Mahābhāṣya of Patañjali, 7).

72 atha dravye padārthe katham vigrahạ kartavyaḥ?

siddhe śabde 'rthasaṃbandhe ceti. nityo hy-arthavatām-arthair-abhisaṃbandhạ̣ (Kielhorn, Patañjali, 7). 
dravya. But it is suggested that dravya is considered the permanent substance here. In this case, dravya is opposed to ākrti as the impermanent form this substance temporarily acquires. ${ }^{73}$

(4) The vārttikā is analyzed as siddhe śabde 'rthe sambandhe ca "the word, referent, and relation [between them] being permanent." The referent is again $\bar{a} k r t i . \bar{A} k r t i$ here is understood as the form, previously considered to be impermanent. Now it is claimed that even the form can be considered permanent, since having ceased to exist in one place, it still exists somewhere else in some other material substrate (dravya). ${ }^{74}$

(5) The vārttika is analyzed as siddhe sabde 'rthe sambandhe ca "the word, referent, and relation [between them] being permanent." It is not important what the referent is: it is enough to underline that it is permanent. ${ }^{75}$

Different attitudes are enumerated in this passage in order to demonstrate that different views on the nature of the referent of the word can be supported by alternative readings of the vārttika. The problem of whether words refer to universals or to individual objects has been discussed by grammarians before Patañjali. In this passage, he evidently plays with different meanings of the terms dravya and akrti, aiming to demonstrate that each interpretation can be justified. The fifth item on the list is probably intended to support the notion of grammar as the universal discipline, compatible with different philosophical doctrines. The same message is expressed in the prior discussion of whether the word is permanent, or to be produced. ${ }^{76}$ Elsewhere, Patañjali claims that grammar embraces all other traditions: sarvavedapārișadam hīdaṃ śāstram. ${ }^{77}$

It should be mentioned that Patañjali does not specify which view is the most convincing to him. It is probably his intention to discuss and justify mutually exclusive views in order to represent the full range of opinions. Different views may complement each other, highlighting different aspects of reality.

73 athavā dravya eva padārtha eșa vigrahạ nyāyyah siddhe śabde 'rthe saṃbandhe ceti. dravyaṃ hi nityam-ākṛtir-anityā (Kielhorn, Patañjali,7).

74 ākṛtav-api padārtha eșa vigraho nyāyyah siddhe śabde 'rthe sambandhe ceti.

nanu coktam-ākṛtir-anityeti.

naitad-asti. nityākṛtih.

katham?

na kvacid-uparateti kṛtvā sarvatroparatā bhavati dravyāntarasthā tūpalabhyate (Kielhorn, Patañjali, 7).

75 athavā kiṃ na etenedạ̣ nityam-idam-anityam-idam-iti. yan-nityaṃ tạ̣ padārthaṃ matvaișa vigrahạ kriyate siddhe śabde 'rthe saṃbandhe ceti (Kielhorn, Patañjali, 7).

76 Kielhorn, Patañjali, 6.

77 Kielhorn, Patañjali, 400. 
Similar trends were noticed in Brāhmmanic texts with their distinction of different levels of description (adhyātma, adhiyajña, adhidaiva), each being valid in a certain context. Later on, a similar approach became the distinctive feature of Bhartṛhari's perspectivism.

Despite the general expectation that a commentary text must contain dialogues of an agonistic type, with the pūrvapakșa refuted and uttarapakșa established, in these two passages from the "Paspaśā," dialogues appear as discursive devices. The dialogue form is employed for the sake of comprehensiveness because the utterances of different speakers complement each other, in sum creating a multidimensional outlook.

\section{Conclusion}

Indian traditions of dialogue on ritualistic, philosophical, and scholastic topics originated in the agonistic verbal contests of the Vedic poets and reached their pinnacle in the agonistic classical $v \bar{a} d a$. Textual evidence from the period in between presents a vast variety of dialogues that were not agonistic, ranging from the fixed, ritualized exchange of riddles to dialogue as a narrative device, and from disputes on secret, nondiscursive matters to the instruction of a pupil by a teacher. In many cases, the dialogues in the texts do not represent instances of actual communication; rather, they appear as narrative devices. As a result, the focus of my study has shifted gradually from matters of social interaction to textual practice. The dialogue form enables the authors to examine different viewpoints in order to present a comprehensive perspective of the universe or other issues under consideration. There would be no point in trying to trace the direct continuity between different types of nonagonistic communication, as represented in the Brāhmaṇas, Upaniṣads, and the $M B h$. But it was the general tendency toward inclusivism and polyphony that stipulated the development of textual practices of a nonagonistic character in premodern Indian culture. These tendencies can and should be traced in the further history of Indian philosophy.

\section{Abbreviations}

Rgveda

Vājasaneyi Saṃhitā

Bṛhadāraṇyaka Upaniṣad

Chāndogya Upaniṣad
(ṚV)

(ChU) 


\section{Bibliography}

Aussant, Émilie. "Vyākaraṇic Texts and Śāstric Discourse." The Journal of Value Inquiry 49, no. 4 (2015): 551-566.

Bakhtin, Mikhail. Problems of Dostoevsky's Poetics, edited and translated by Caryl Emerson. Minneapolis: University of Minnesota Press, 1984.

Black, Brian. The Character of the Self in Ancient India: Priests, Kings, and Women in the Early Upanishads. Albany: State University of New York Press, 2007.

Brereton, Joel P. “'Why Is a Sleeping Dog Like the Vedic Sacrifice?': The Structure of an Upanișadic Brahmodya." In Inside the Texts, Beyond the Texts: New Approaches to the Study of the Vedas, edited by Michael Witzel, 1-14. Cambridge: Department of Sanskrit and Indian Studies, Harvard University, 1997.

Brereton, Joel P. “Edifying Puzzlement: Rgveda 10. 129 and the Uses of Enigma." Journal of the American Oriental Society 119, no. 2 (1999): 248-260.

Elizarenkova, Tatyana, and Toporov, Vladimir. "Drevneindiyskaya poetika i ee indoevropeyskiye istoki." In Literatura i kultura drevney i srednevekovoy Indii, edited by Georgiy Zograf and Vladimir Erman, 36-88. Moscow, Nauka: 1979.

Elizarenkova, Tatyana, and Toporov, Vladimir. "O vediyskoy zagadke tipa brahmodya." In Paremiologicheskiye issledovaniya, edited by Grigiriy Permyakov, 14-46. Moscow: Nauka, 1984.

Elizarenkova, Tatyana. Rigveda: Mandaly I-IV. Moscow: Nauka, 1999.

Halbfass, Wilhelm. India and Europe. New York: State University of New York Press, 1988.

Halbfass, Wilhelm. On Being and What There Is: Classical Vaiśeșika and the History of Indian Ontology. New York: State University of New York Press, 1992.

Heesterman, Johannes Cornelis. "Brahmin, Ritual and Renouncer." Wiener Zeitschrift für die Kunde Süd- und Ostasiens 8 (1964): 1-31.

Heesterman, Johannes Cornelis. "On the Origin of the Nāstika." Zeitschrift für die Kunde Südund Ostasiens 12-13 (1968-69): 171-186.

Hock, Hans Henrich. "The Yājñavalkya Cycle in the Bṛhadāraṇyaka Upanișad.” Journal of the American Oriental Society 122, no. 2 (2002): 278-286.

Houben, Jan E. M. The Sambandha-samuddeśa. Chapter on Relation and Bhartrhhari's Philosophy of Language. Groningen: Gonda Indological Studies, 1995.

Houben, Jan E. M. "The Ritual Pragmatics of a Vedic Hymn: The 'Riddle Hymn' and the Pravargya Ritual.” Journal of the American Oriental Society 120, no. 4 (2000): 499-536.

Johnson, Willard. "On the RG Vedic Riddle of the Two Birds in the Fig Tree (RV 1.164.20-22), and the Discovery of the Vedic Speculative Symposium." Journal of the American Oriental Society 96, no. 2 (1976): 248-258.

Kielhorn, Franz, ed. The Vyākaraṇa-Mahābhāṣya of Patañjali. Vol. 1. Bombay: Government Central Book Depot, 1880.

Kuiper, Franciscus. “The Ancient Aryan Verbal Contest.” Indo-Iranian Journal 4 (1960): 217-281.

Malamoud, Charles. "The Gods Have No Shadows: Reflections on the Secret Language of the Gods in Ancient India." In Cooking the World: Ritual and Thought in Ancient India, translated by David White, 195-206. Delhi: Oxford University Press, 1996.

Olivelle, Patrick. The Early Upanishads: Annotated Text and Translation. Oxford: Oxford University Press, 1998. 
Renou, Louis. “Le Passage des Brahmaṇa aux Upanișad.” Journal of the American Oriental Society 73, no. 3 (1953): 138-144.

Sementsov, Vsevolod. Problemy interpretatsii brahmanicheskoy prozy. Moscow: Nauka, 1981.

Slaje, Walter. "Water and Salt (I): Yājñavalkya’s Saindhava Dṛștānta (BĀU II 4, 12)." IndoIranian Journal 44 (2001): 25-57.

Thompson, George. "The Brahmodya and Vedic Discourse." Journal of the American Oriental Society 117 (1997): 13-37.

Vasilkov, Yaroslav. “Did East and West Really Meet in Milinda's Questions?” Petersburg Journal of Cultural Studies 1 (1993): 64-77.

Vasilkov, Yaroslav. Mif, ritual i istoria v “Mahabharate.” St. Petersburg: Evropeyskiye issledovaniya, 2010.

Watkins, Calvert. How to Kill a Dragon: Aspects of Indo-European Poetics. Oxford: Oxford University Press, 1995.

Weber, Albrecht, ed. The Vājasaneyi-Saṃhitā in the Mādhyandina and Kānva-Śākhā with the Commentary of Mahidhara. Varanasi: Chowkhamba, 1972.

Witzel, Michael. On Magical Thought in the Veda (Inaugural Address, Leiden University). Leiden: Universitaire Pers Leiden, 1979. 
